\title{
Genetic Transformation in Rhizobium
}

\author{
By J. L. RAINA AND V. V. MODI \\ Department of Microbiology, \\ M.S. University of Baroda, Baroda, India \\ (Accepted for publication 2I March I969) \\ SUMMAR Y
}

\begin{abstract}
Mutants of ground nut (Rhizobium cowpea group) strain GR 3 were isolated using ultraviolet radiation and $N$-methyl- $N^{\prime}$-nitro- $N$-nitrosoguanidine (NTG) as mutagenic agents. An adenine-requiring mutant was used as the recipient and its wild type as the donor in transformation studies. Initially minimal medium supplemented with $2 \mu \mathrm{g}$. adenine $/ \mathrm{ml}$. was used for the development of competence. The maximum transformation frequency was obtained after about $120 \mathrm{~min}$. incubation. Supplementation of minimal medium with yeast extract and vitamin-free Casamino acids without the addition of adenine stimulated competence to a large extent. The competence was not further stimulated by any of the divalent ions used. The optimum DNA concentration for maximum transformation frequency was about $50 \mu \mathrm{g} . / \mathrm{ml}$.
\end{abstract}

\section{INTRODUCTION}

Ravin (196I) listed more than 20 bacterial species which have been found to be transformable inter-specifically or intra-specifically. Ravin (I96I) also commented on transformation in Rhizobium reported by Balassa (1955, 1957, 1960). The original reports do not however contain detailed accounts of the procedures used.

Since then well-defined methods of genetic transformation have been established in Streptococcus, Diplococcus, Pneumococcus, Haemophilus and various strains of Bacillus subtilis. Considerable information is available regarding the competence state of the recipient cell, uptake of DNA, integration of DNA and expression of phenotypic characters. Such studies on a transformation system in Rhizobium would be helpful in several ways; for example, whether the mechanism of transformation in other organisms applies to Rhizobium and also whether transformation could be used to study the mechanism of the nitrogen fixation, elucidation of the genetic elements involved and ultimately the exploration of better and more efficient nitrogen fixing strains with a wide host range. More recently studies on genetic transformation between species and genera of various organisms have been extended to establish the taxonomic relationships between them (Marmur, Falkow \& Mandel, 1963; De Ley, 1964).

Earlier we confirmed that some strains of Rhizobium are transformable (Gadre, Mazumdar, Modi \& Parekh, 1967). Further efforts reported here were made to establish methods for demonstrating genetic transformation in Rhizobium. 


\section{METHODS}

Strain. The strain GR 3 of Rhizobium originally isolated from ground nut host nodules belonging to the cowpea group was kindly supplied by Dr V.P. Bhide, Poona, India. The purity of the culture was tested before use and was maintained on mannitol yeast extract agar medium and subcultured every 15 days.

Media. Complex medium: $\mathrm{K}_{2} \mathrm{HPO}_{4}, 0.36 \% ; \mathrm{KH}_{2} \mathrm{PO}_{4}, 0.04 \% ; \mathrm{MgSO}_{4} \cdot 7 \mathrm{H}_{2} \mathrm{O}$, $0.005 \% ; \mathrm{NaCl}, 0.05 \% ;\left(\mathrm{NH}_{4}\right)_{2} \mathrm{SO}_{4}, 0 . \mathrm{I} \%$; yeast extract (Difco) $0 . \mathrm{I} \%$; vitamin-free Casamino acids (Difco) $0.1 \%$ and glucose $0.1 \%$. Development of competence was investigated in medium of the following composition: $\mathrm{K}_{2} \mathrm{HPO}_{4}, 0.7 \% ; \mathrm{KH}_{2} \mathrm{PO}_{4}$, $0.2 \%$; Na-citrate. $2 \mathrm{H}_{2} \mathrm{O}, 0.0 \mathrm{I} \% ; \mathrm{MgSO}_{4} .7 \mathrm{H}_{2} \mathrm{O}, 0.05 \%$; glucose $0.2 \%$ and adenine $2 \mu \mathrm{g} . / \mathrm{ml}$. Medium of this composition containing $\mathrm{I} \cdot 5 \%$ (w/v) agar (Difco) without adenine was used for measuring the efficiency of transformation to prototrophy. This competence medium was supplemented with Difco yeast extract and vitamin-free Difco Casamino acids ( $\mathrm{I} \mathrm{mg} . / \mathrm{ml}$. each) for the stimulation of competence. The optimum DNA concentration and effect of divalent ions on competence was investigated using this medium.

Isolation and characterization of mutants. Auxotropic mutants of strain GR 3 were isolated using u.v. irradiation and $N$-methyl- $N^{\prime}$-nitro- $N$-nitrosoguanidine (NTG) (Aldrich Chemicals, U.S.A.) as the mutagenic agents. Initially, u.v. survival curves and NTG inactivation curves were studied. NTG inactivation was studied in acetate buffer $0.2 \mathrm{M}$ at $\mathrm{pH} 5.0$ and in complex medium. An overnight culture was inoculated into fresh complex medium and incubated for $4 \mathrm{hr}$ on a shaker at $30^{\circ}$, centrifuged and the pellet resuspended in acetate buffer and complex medium containing I $\mathrm{mg}$. NTG/ml. At regular intervals samples were removed and after appropriate dilutions plated on complex agar medium, incubated for $24 \mathrm{hr}$ at $30^{\circ}$ and the colonies were counted. These plates were replicated on to minimal agar plates to estimate the fraction of mutants amongst the survivors. In each case when the survival reached about $0.2 \%$ a sample was incubated overnight in complex medium and the penicillin selection methods of Davis (1949) and Lederberg \& Zinder (1948) used for the concentration of mutants. The replica plating technique of Lederberg \& Lederberg (1952) was used for the characterization of the mutants isolated. A stable adenine-requiring mutant capable of growing optimally at $20 \mu \mathrm{g}$. adenine $/ \mathrm{ml}$. on agar medium was selected as the recipient.

Preparation of transforming DNA and its estimation. An overnight culture of adenine-independent strain GR 3 grown in complex medium was inoculated in fresh medium of the same composition at a cell density of about $\mathrm{I} \times 10^{6} \mathrm{cells} / \mathrm{ml}$. and incubated on a rotary shaker for $8 \mathrm{hr}$ at $30^{\circ}$. The cells were collected by centrifugation at 0 to $4^{\circ}$, washed twice with saline-EDTA (0.15 $\mathrm{M}-\mathrm{NaCl}$ and $0.1 \mathrm{M}-E D T A, \mathrm{pH} 7.0$ \pm 0.2 ) and DNA was extracted by following the method of Marmur (I96I) with the modification that after complete lysis of cells Pronase (Calbiochem) I mg./ml. of lysate was added and incubated at $37^{\circ}$ for $6 \mathrm{hr}$ (Berns \& Thomas, 1965). The DNA after isopropanol precipitation was taken up in sterile saline citrate $(0.15 \mathrm{M}-\mathrm{NaCl}$ and 0.015 M-sodium citrate, $\mathrm{pH} 7 \cdot 0$ ) and preserved over a layer of chloroform at o to $4^{\circ}$. DNA was estimated by the diphenylamine reaction and o.D. was measured at $600 \mathrm{~m} \mu$. u.v. absorption of the samples was noted spectrophotometrically at $260 \mathrm{~m} \mu$. Bacillus subtilis DNA was taken as the standard in both the cases. 
Determination of competence. An overnight recipient culture grown in the complex medium was centrifuged and after washing with standard phosphate buffer $(\mathrm{pH} 7 \cdot 0)$ suspended in fresh medium of the same composition to a density of $I \times 10^{6}$ organisms/ $\mathrm{ml}$. and incubated on a rotary shaker at $30^{\circ} \pm 2$ for $4 \mathrm{hr}$. Thereafter the culture was centrifuged, washed twice as before and resuspended again in competence medium. Every $30 \mathrm{~min}$. the culture was removed for studying competence and DNA $(25 \mu \mathrm{g}$./ $\mathrm{ml}$.) was added to make the final volume to I ml. Incubation was carried out at $30^{\circ} \pm$ $2^{\circ}$ for $30 \mathrm{~min}$. and the reaction terminated by adding DNase $50 \mu \mathrm{g}$. $/ \mathrm{ml}$. containing $5 \mathrm{mM}-\mathrm{MgCl}_{2}$. The culture was then incubated for $30 \mathrm{~min}$. and after appropriate dilution plated on minimal medium to select for the transformants and on adenine (20 $\mu \mathrm{g}$. $/ \mathrm{ml}$.) supplemented medium for the total count. The plates were incubated for $48 \mathrm{hr}$ and the colonies counted. The controls included (I) plating the culture without DNA treatment, (2) recipient treated with recipient DNA, (3) plating of donor DNA alone, (4) addition of DNase before adding DNA and (5) treatment with DNA isolated from an unrelated organism such as Bacillus subtilis. No growth was noted after $48 \mathrm{hr}$ of incubation in any of the controls. When the transformation reaction was terminated by DNase after $30 \mathrm{~min}$. of incubation the transformation frequency obtained was $0.04 \%$ (Table I). Competence of the culture was studied in the medium described earlier and for further studies the same medium supplemented with yeast extract ( $\mathrm{r} \mathrm{mg} . / \mathrm{ml}$.) and vitamin-free Casamino acids ( $\mathrm{I} \mathrm{mg./ml.)} \mathrm{was} \mathrm{used.}$

\section{Table I. Transformation of adenine-requiring recipient to prototrophy}

Incubation with

Wild-type DNA

Wild-type DNA treated with DNase

Recipient DNA

Bacillus subtilis DNA

$\begin{array}{cc}\begin{array}{c}\text { No. of } \\ \text { colonies on } \\ \text { minimal agar }\end{array} & \begin{array}{c}\text { Transformation } \\ \text { frequency } \\ (\%)\end{array} \\ 4 \times 10^{4} & 0.04 \\ 0 & - \\ 0 & - \\ 0 & -\end{array}$

RESULTS

The lethal effect of NTG on the cells in acetate buffer and complex medium is shown in Fig. I. Residual NTG was removed before plating by serial dilution. The rate of inactivation in complex medium was twice that in buffer and the frequency of mutants increased gradually to a maximum of $20 \%$. The fraction of the mutants amongst the survivors was almost the same in buffer and in complex medium. The ultra-violet survival curve showed that $2 \cdot 0 \%$ survival was obtained within $300 \mathrm{sec}$. under standard conditions of exposure.

\section{Growth curves}

For the transformation experiments the growth curve of the adenine-requiring recipient was measured in complex medium as well as in minimal medium supplemented with adenine $20 \mu \mathrm{g} . / \mathrm{ml}$. The lag period was twice as long in the supplemented medium as in the complex medium (Fig. 2). The culture remained in the log. phase for 6 to $7 \mathrm{hr}$ and thereafter the stationary phase set in. At the end of the log. phase the cultures reached the same optical density in both media. It can be seen that the 
phasing of the cultures is slightly different in the two media and this difference might be responsible for the increase in the number of transformants when the competence medium was used.

\section{Competence and age of culture}

Figure 3 shows the number of transformants obtained as a function of the age of the culture in minimal medium (competence medium) and medium supplemented with yeast extract and Casamino acids. In both media the culture attains maximum competence between 90 and $\mathrm{I} 80 \mathrm{~min}$. incubation but in supplemented competence medium the number of transformants obtained was higher than in minimal competence

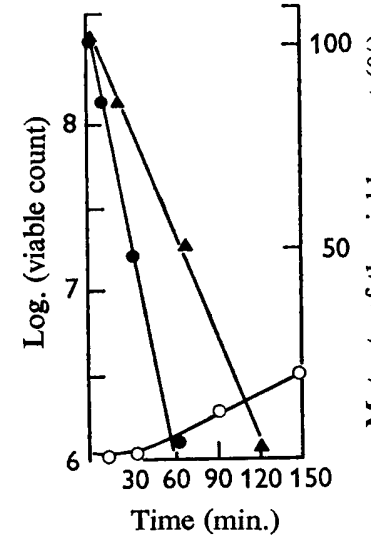

Fig. I

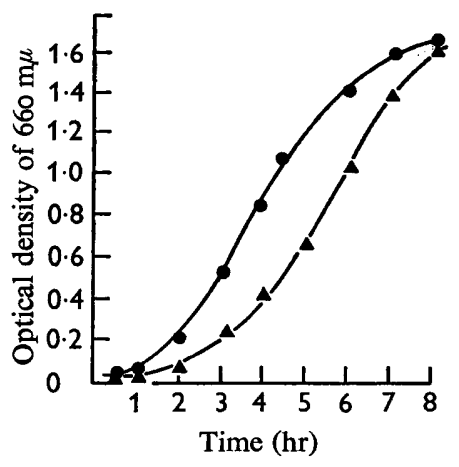

Fig. 2

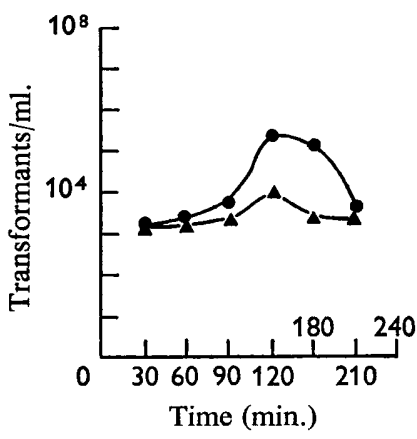

Fig. 3

Fig. I. $N$-methyl- $N^{\prime}$-nitro- $N$-nitrosoguanidine (NTG; I mg./ml.) inactivation curve in complex medium $(\boldsymbol{O})$, acetate buffer $(\boldsymbol{\Delta})$ and occurrence of mutants $(O)$ as a function of time.

Fig. 2. Growth curves of the recipient in complex medium (O) and adenine $(20 \mu \mathrm{g} . / \mathrm{ml}$.) supplemented minimal medium $(\boldsymbol{\Delta})$.

Fig. 3. Competence and age of the culture in minimal medium supplemented with $2 \mu \mathrm{g}$. adenine $/ \mathrm{ml}$. ( $\Delta)$ and minimal medium supplemented with yeast extract $(\mathrm{I} \mathrm{mg} . / \mathrm{ml}$.) and vitamin-free Casamino acids ( $\mathrm{I} \mathrm{mg}$. $/ \mathrm{ml}$.) (๑). Total count between $2 \cdot 2 \times 10^{8}$ and $1 \cdot 9 \times 10^{9} / \mathrm{ml}$.

medium, indicating that the supplementation causes stimulation of competence. Any further increase in the concentration of yeast extract and Casamino acids interfered with the recovery of the transformants by supporting the growth of non-transformants on the selective minimal agar medium.

\section{Determination of optimum DNA concentration}

After $120 \mathrm{~min}$. incubation in the competence medium the culture was removed and treated with various concentration of DNA. The saturating concentration of DNA necessary for maximum transformation was about $50 \mu \mathrm{g} . / \mathrm{ml}$. (Table 2). Increase in the number of transformants was roughly proportional to the amount of DNA added until a concentration of $50 \mu \mathrm{g} . / \mathrm{ml}$. is reached. Concentrations of DNA above $50 \mu \mathrm{g}$./ $\mathrm{ml}$. decreased the number of transformants slightly. 
Effect of divalent ions on competence

Leonard, Mattheis, Mattheis \& Housewright (1964) and Young \& Spizizen (1963) studied the effect of divalent ions on transformation in Bacillus licheniformis and B. subtilis respectively. The divalent ions used (Table 3) did not show any stimulation but instead there was a large decrease when $\mathrm{Fe}$ was used and a moderate decrease when $\mathrm{Cu}, \mathrm{Mo}, \mathrm{Zn}, \mathrm{Mg}$ and $\mathrm{Ca}$ were used as compared to the control. The concentrations used were not toxic to the organisms since no effect on the total count of the culture at the time of transformation was observed. Each experimental tube was inoculated with $\mathrm{I} \cdot 5 \times 1 \mathrm{I}^{7}$ organisms $/ \mathrm{ml}$ and the total count at the time of transformation ranged between $9.8 \times 10^{7}$ and $1 \cdot 2 \times 10^{8} / \mathrm{ml}$. in all the tubes. We conclude that the transformation process was affected at some stage by the ions used.

Table 2. Effect of DNA concentration on transformation

$\mu \mathrm{g}$. DNA added Transformants/ml.

$\begin{array}{rl}0.1 & 8.6 \times 10^{1} \\ 1 \cdot 0 & 1.1 \times 10^{2} \\ 10.0 & 2.4 \times 10^{2} \\ 20 \cdot 0 & 5.0 \times 10^{2} \\ 30 \cdot 0 & 8.1 \times 10^{2} \\ 40 \cdot 0 & 2.0 \times 10^{3} \\ 50.0 & 2.2 \times 10^{4} \\ 55.0 & 2.2 \times 10^{4}\end{array}$

Total count between $5 \times 10^{8}$ and $6 \cdot 5 \times 10^{8} / \mathrm{ml}$.

Table 3. Effect of divalent ions on competence

Ions added* Transformants/ml.

$\begin{array}{lr}\mathrm{None} & \mathrm{I2}, 000 \\ \mathrm{Cu} & 100 \\ \mathrm{Zn} & 110 \\ \mathrm{Mo} & 170 \\ \mathrm{Mg} & 190 \\ \mathrm{Fe} & 30 \\ \mathrm{Ca} & 50\end{array}$

Total count $9 \cdot 8 \times 10^{7}-\mathrm{I} \cdot 2 \times 10^{8} / \mathrm{ml}$.

* The medium was supplemented with $\mathrm{CuSO}_{4}, \mathrm{ZnCl}_{2},\left(\mathrm{NH}_{4}\right) \mathrm{MoO}_{2}, \mathrm{MgSO}_{4} \cdot 7 \mathrm{H}_{2} \mathrm{O}, \mathrm{FeSO}_{4}$ and $\mathrm{CaCl}_{2}(5 \mu \mathrm{g} . / \mathrm{ml}$.) as indicated.

These results show that an adenine-requiring mutant, isolated from the parent strain GR 3, could be transformed by its parent DNA and as is known for some of the other Rhizobium species, competence is essentially attained in the early log. phase. It was necessary to maintain the culture in a good physiological condition to attain maximum transformation frequency and the temperature had to be maintained at $30^{\circ} \pm 2^{\circ}$.

This enquiry was supported in part by the Council of Scientific and Industrial Research and grant No. PL-480/FG-IN-394 from the Agricultural Research Service of the U.S. Department of Agriculture. 


\section{REFERENCES}

Balassa, R. (1955). In vivo induzierte Transformationen bei Rhizobien. Nátúrwissenschaften. 43, 422.

Balassa, R. (1957). Durch desoxyribonukleinsauren induzierte veranderungen bei Rhizobien. Acta microbiol. hung. 4, 77.

BalASSA, R. (1960). Transformation of a strain of Rhizobium lupini. Nature, Lond. 188, 246.

BERNs, K. I. \& THOMAS, C. A. (I965). Isolation of a high molecular weight DNA from Hemophilus J. molec. Biol. II, 476.

Davis, B. D. (1949). Isolation of biochemically deficient mutants by penicillin. Proc. natn. Acad. Sci. U.S.A. 35, I.

De LeY, J. (1964). Pseudomonas and related genera. A. Rev. Microbiol. 18, I7.

Gadre, S. V., MAZumdar, L., Modi, V. V. \& ParekH, V. (I967). Interspecific transformation in Rhizobium. Arch. Mikrobiol. 57, 388.

LEDERBERG, J. \& ZINDER, N. (1948). Concentration of biochemical mutants of bacteria with penicillin. J. Am. chem. Soc. 70, 4267.

LEDERBERG, J. \& LEDERBERG, E. M. (I952). Replica plating and indirect selection of bacterial mutants. J. Bact. 63, 399.

Leonard, C. G., Mattheis, D. K., Mattheis, M. J. \& Housewright, R. D. (I964). Transformation to prototrophy and polyglutamic acid synthesis in Bacillus licheniformis. J. Bact. 88, 220.

MARMUR, J. (I96I). A procedure for isolation of DNA from micro-organisms. J. molec. Biol. 3, 208. Marmur, J., Falkow, S. \& Mandel, M. (1963). New approaches to bacterial taxonomy. A. Rev. Microbiol. 17, 329.

Ravin, A. W. (I96I). The genetics of transformation. Adv. Genet. ro, 6I.

YouNG, F. E. \& SPIZIzEN, J. (1963). Incorporation of DNA in Bacillus subtilis transformation system. J. Bact. 86, 392. 